\title{
A Clinical Study on Efficacy of Dawae Akyas in Management of Benign
} Ovarian Cyst

\author{
Authors \\ Asiya Farheen ${ }^{1 *}$, Wasia Naveed ${ }^{1}$, Shazadi Sultana ${ }^{1}$, S.Afsar Ali ${ }^{2}$, \\ NMA Rasheed ${ }^{2}$, Asema Mahveen ${ }^{1}$ \\ *Corresponding Author \\ Asiya Farheen
}

\begin{abstract}
Background: Ovarian cyst / Dawera Mubayaz is a common gynaecological problem that can occur in any women at any age. In symptomatic women intervention is sometimes necessary to alleviate symptoms and cyst recurrence. Ibne Sina mentioned that Akyas / Dawera-e-Mubayaz are a type of localised swellings (inflammation) mainly due to localised or generalised accumulation of abnormal phlegm (Ghair Tabyi Khilte Balgham).

Aims and Objectives: Objectives of this study is to find out alternative management of ovarian cyst by polyherbal formulation (Dawae Akyas).

Materials and Methods: This prospective clinical study included sixty individuals on the basis of examination as well as on sonography and CA-125 report.

Results: This study shows a significant response with $P<0.001$ value, in terms of cyst resolution, relieving symptoms and correction of abnormal temperament.

Conclusion: It is concluded that Unani polyherbal formula (Dawae Akyas) not only resolves the cyst but it relieves complaints of the participants and correct their overall health.
\end{abstract}

Keywords: Ovarian Cyst, Dawae Akyas, Unani Polyherbal Formulation, Balghami Mizaj, Ultrasonography, Cancer Antigen-125.

\section{Introduction}

An ovarian cyst is a larger fluid-filled sac or follicle or corpus luteum (more than $3 \mathrm{~cm}$ in diameter) persists and continue growing on or in an ovary. A cyst can vary in size from a few centimeters to the size of a large melon. Ovarian cysts may be thinwalled and only contain fluid (known as a simple cyst) or they may be more complex, containing thick fluid, blood or solid areas ${ }^{[1]-[3]}$. Ovarian enlargements cystic or solid may occur at any age, functional and inflammatory enlargements of the ovary develop almost exclusively during the child bearing years. It is usually due to accumulation of fluid inside the functional unit of the ovary or may be the result of persistence enlargement of physiological structures in the ovary like the Graafian follicle or corpus luteum ${ }^{[4],[5]}$. They may be asymptomatic or produce local discomfort, menstrual disturbance, infertility, or in rare cases cause acute symptoms due to complications like hemorrhage, rupture or torsion. In asymptomatic women the management of these cysts should be expectant as they usually regress spontaneously. A 
repeat examination after 6-weeks should be performed to confirm resolution. However, large functional cysts can cause pelvic pain, and occasionally ovarian torsion. In symptomatic women intervention is sometimes necessary to alleviate symptoms. The definition of huge ovarian cysts is not well described in the literature. Some authors define large ovarian cysts as those that are more than $10 \mathrm{~cm}$ in diameter as measured by preoperative scans ${ }^{[4],[6]-[8]}$.

An ovarian cyst diagnosed during the reproductive age is rarely malignant, nevertheless, as a rule a finding of an ovarian cyst $>5 \mathrm{~cm}$, should be followed up and if persistent a workup should include a medical history, physical examination, imaging tools and laboratory test and markers should be performed if findings are suspicious to rule out malignancy or surgical evaluation is often required for persistent cysts. Cyst wall cells or cyst wall produce the fluid and are thus responsible for the growth and persistence of the cyst. Persistence or recurrence after cyst aspiration reported in the literature range from $11 \%$ to $65 \%$. The risk of ovarian malignancy increases with age, a number of investigations

have confirmed the safety of this approach when several criteria are met: Sonographic evidence of a thin-walled, unilocular cyst, cyst diameter less than $5 \mathrm{~cm}$, No cyst enlargement during surveillance, and Normal serum CA-125 level ${ }^{[9]-[12]}$.

The aim of this study is to find out the efficacy of Unani medicine in the treatment of ovarian cysts, to restore the reproductive function, to prevent recurrence of cyst and to avoid surgical intervention. Incidence: The epidemiology of ovarian cysts is unclear due to the lack of consistent reporting and a high likelihood of spontaneous resolution. Worldwide, about $7 \%$ of women have an ovarian cyst at some point in their lives. During the reproductive years, the most common ovarian masses are benign. Most ovarian tumors (80\% to $85 \%)$ are benign, and two-thirds of these occur in women between 20 and 44 years of age. The chance that a primary ovarian tumor is malignant in a patient younger than 45 years of age is less than 1 in (15) fifteen ${ }^{[13-15]}$.

UNANI Concept: According to Unani medicine cyst is considered as a type of viscid inflammation, enveloped by a sac of membranous tissue. Ibn-eSina(980-1037 AD), illustrated it under the heading of Warm-e-Balghami;as it is a swelling filled with viscid phlegm (Balgham-e-Ghaleez) ${ }^{[16,17]}$.

Definition: In Unani system of medicine, an ovarian cyst is known as Dawerae Mubayaz Ek Khana/ Esteskhai khusyat-ur-Rehm Ek Khana / Kesa-e-Khusyat-ur-Rehm. The description of Dawerae Mubayaz is present in literature since ancient period and defined as: In this disease white watery or light reddish viscous fluid accumulates in the ovarian sac. The shape of ovarian sac becomes like a bag filled with water, and this sac slowly ascends towards abdomen from pelvis ${ }^{[18-20]}$.

Causes of Ovarian Cyst According to Unani

Medicine: There are different causative theories, according to ancient physicians it is due to structural weakness of ovaries or impurities of blood (FasaadE-khoon) due to which nutrients of the ovaries does not absorb in the structure of the ovaries, hence abnormal accumulated fluid (morbid humors) forms cyst; Nuqs-E-Taqziyah(malnutrition).The important cause is ascribed as to dominance of abnormal phlegm (GhairTab'yiKhilth-e-Balgham) in the blood. Shaik- Ul -Raes Ibn-e-Sina(980-1037 AD) mentioned that these type of cysts (Akyas / Sula' / Dawerae) are a type of localised swellings (inflammation), mainly due to localised or generalized accumulation of abnormal phlegm (balgham). This ovarian disorder is predominant in women of 30to 40 years of age group, irrespective of marital status. Frequently in women suffering with uterine diseases ${ }^{[16-20]}$.

\section{Line of Treatment (Usool-E-Ilaj): Hippocrates} postulated that when wrong proportion and altered equilibrium of humours that is imbalanced temperament is corrected health can be recovered. In Unani medicine after diagnosing the disease, principle of management (usool-e-ilaj) of disease is determined on the basis of etiology and associated factors on the following pattern: 
(1) Tadeele akhlat (Normalization of humour).

(2) Izalae sabab or Tanqiyah Mawad (Elimination of cause).

(3) Tadeele aaza (Normalization of tissues or organs) ${ }^{[17-21]}$.

Selection of the Drugs: Selection of the drugs is made as mentioned in ancient books of Unani system for the treatment of ovarian cysts and female reproductive irregularities and coded name is given as Dawae Akyas. The properties of the drugs are blood purifier(Musafi-e-Khon), resolvent (Muhalili-Waram), carminative(Kasir-e-Riyah), diuretics (Mudir), emmenogogue (Mudir-e-Haiz), antiinflammatory (Muhalil-i-Warm) ,antiseptic and detoxificant (Dafa-e-Taffun), laxative(Mulayyin), analgesic (Musakkin-i-Alam), repellent(RadaeMavad), detergent(Jali), absorbent(Jaazib-eRutoobat), astringent (Qabiz), tonic(Muqawi Azae Raisah) and aphrodisiac (Muqawi-e-Azae-Tanasil) [17, 20-24]. The pharmacognosy of these polyherbal formulations (Dawae Akyas) revealed that they have Steroidal and alkaloidal effects. The alkaloides are useful in the treatment of hormonal imbalance of female reproductive system. The other contents of these drugs like iron, magnesium, calcium, potassium, zinc provide tonic effect on the overall health of an individual ${ }^{\text {[25-27]. }}$.

Management: The management of an ovarian cyst is still a challenge to gynaecologists due to the inherent character of these cysts; the recurrence which imposes its burden on the psychological status of patients and so affects their quality of life and endangers their fertility especially in case of endometrioma, or management depends on their presentation. The treatment options includes conservative follow up, medical treatment and surgical management ${ }^{[9,11,28]}$. In Unani system of medicine, second mode of treatment i.e. pharmacotherapy (Ilaj Bil Dawa) is enriched with vast number of single (Mufrad) and compound (Murakkab) drugs for the treatment of ovarian cyst [18].

\section{Material and Methods}

This was a hospital based prospective study carried out in Department of Amraaz-e-Niswan (Gynecology) at Govt. Nizamia General Hospital, Hyderabad. The study included all women who came to Gynaecology Department with a history of abdominal pain, menstrual irregularities, infertility, who were ruled out of ovarian cyst on examination as well as on USG. All patients were evaluated by detailed history, general and local examination, routine and special investigations viz complete blood picture, random blood sugar, thyroid profile, liver function tests, and cancer antigen test (CA125). The Mizaj of the patients was evaluated on standard parameters (Alamat-e-Ajnase-e-Ashra) as described in the classical Unani text. The cancer antigen test (CA-125) and USG was done to confirm diagnosis and exclude cases (whenCA-125 was $>35$ International Units $/ \mathrm{mL}$, with suspicious malignant sonographic criteria). The study was done for a period of three years from February- 2016 to February - 2019. A total of 60 study participants were enrolled in the study. Clinical treatment with Dawae Akyas given for two weeks every month for three months and follow up for next three months. Dawae Akyas consists of oral classical joshanda (decoction), sufoof (powder) and locally zimad (Ointment, applied locally on effected side ( Jof-eAana).

Statistical Analysis: After data is analysed by simple proportions, final results are entered in Microsoft excel sheet. Percentage is used to mention the frequency of ovarian cysts in the population studied. In our study most variables were quantitative, so analysis done by non-parametric test (Chi-squared test) to obtain correlation among ovarian cysts and variables, hence $\mathrm{p}<0.05$ statistically significant.

Institutional Ethics Committee: Institutional ethics committee's permission of Govt.Nizamia General Hospital was obtained before initiating the study and proper registration was done by Clinical Trials Registry -India.

Informed Consent: Informed and written consent was obtained from each participant. 


\section{Results and Discussion}

A total of 60 cases of ovarian cysts were studied based on comprehensive history, general and gynecological examination, on the basis of clinical features.Serum concentration of cancer antigen (CA-125) was done to rule out malignancy. Accurate prediction with nonsurgical methods of whether a cyst is benign or malignant requires a combination of clinical examination, Ultrasonography (USG), and measurement of the serum concentration of CA-125. Ultrasonography is probably the most reliable method, with a diagnostic accuracy of 90-100\% for transvaginal scanning ${ }^{[11]}$.

Table 1: Distribution of study participants according to age

\begin{tabular}{|l|c|c|}
\hline Age(years) & Frequency & Percentage \\
\hline $15-20$ & 13 & 21.7 \\
\hline $21-25$ & 15 & 25.0 \\
\hline $26-30$ & 12 & 20.0 \\
\hline $31-35$ & 10 & 16.7 \\
\hline $36-40$ & 10 & 16.7 \\
\hline Total & 60 & 100.1 \\
\hline
\end{tabular}

The study participants were of different age group and were divided into five groups, to understand the incidence of ovarian cysts among the groups. Majority of participants were (15) i.e. $25.0 \%$ were in the age group of 21-25 years, 13 participants (i.e.21.7\%) were in the age group of 15-20 years and $12(20.0 \%)$ were 26-30years. The mean \pm standard deviation [SD] age was $27.08 \pm 6.92$. These present study findings are compatible with other studies done by Nalini YL et al $66.66 \%$ and Patrick et al $41 \%$, where maximum study participants were in the age group of 21-30 years, followed by $31-40$ years ${ }^{[29]}$.

Table 2: Study participants according to size of cyst. $\mathrm{n}=60$

\begin{tabular}{|l|c|c|}
\hline Size $(\mathrm{cm})$ & Frequency & Percentage \\
\hline $3.0-4.9 \mathrm{~cm}$ & 44 & 73.33 \\
\hline $5.0-5.9 \mathrm{~cm}$ & 07 & 11.7 \\
\hline$\geq 6 \mathrm{~cm}$ & 09 & 15.0 \\
\hline
\end{tabular}

We observed cyst of variable sizes ranging from 3$4.9 \mathrm{~cm}$ in $44(73.33 \%), 5-5.9 \mathrm{~cm}$ in $07(11.7 \%)$ and $\geq$ 6 cmwere in $09(15.0 \%)$ participants. The demographic characteristics of the participants in addition to Temperament (Mizaj) of the participants are illustrated in (Table-3).The Unani scholars had mentioned in the literature that the incidence of ovarian cysts in young, unmarried girls and senile women was less compared to married and parous women ${ }^{[18]}$. These observations of Unani philosophers are comparative with present study vide table 3 .

We observed that incidence was more common among the married women 45 (75.0\%) fewer incidences are seen in unmarried girls that is 15 (25.0\%). Another study by Abduljabbar et al stated that they observed out of 244 patients who were diagnosed with ovarian cysts, 165 were married $(67.4 \%)$.

Based on the occupation, ovarian cysts were more common in house wives $38(63.3 \%)$ than employees $14(23.3 \%)$ or students $08(13.3 \%)$.

Basing on the evaluation of Temperament (Mizaj) of the participants, ovarian cysts were more seen $31(51.7 \%$ ) in phlegmatic temperament ( balghami mizaj) individuals, and second maximum was among Safravi temperament 18 (20.0\%), minimum incidence was seen in Damavi mizaj temperament participants (11i.e., 18.3\%). It shows that participants with balghami mizaj have higher incidence of ovarian cyst compared to others and these findings correlates with temperamental theory of inflammatory conditions.

Regarding the socio-economic status, a total of $27(45.0 \%)$ belonged to middle income group and 22 participants $(36.7 \%)$ were of low income group. High income group participants were only $11(18.3 \%)$. The reason could be as this study was carried out in government centre and high income group participants might not be inclined to approach the government facility.

Table 4: Distribution of study participants according to presentations before and after treatment

\begin{tabular}{|c|c|c|c|c|}
\hline $\begin{array}{l}\text { Before } \\
\text { treatment }\end{array}$ & $\begin{array}{c}\text { After } \\
\text { treatment }\end{array}$ & \multirow{2}{*}{$\begin{array}{l}\text { Remission of } \\
\text { symptoms } \\
(\%)\end{array}$} & \multirow[t]{2}{*}{$\chi^{2 \text {-test }}$} & \multirow[t]{2}{*}{ p-value } \\
\hline \multicolumn{2}{|c|}{ Lower abdomen pain } & & & \\
\hline 46 & 02 & $44(95.7)$ & 80.544 & $<0.00001$ \\
\hline \multicolumn{5}{|c|}{ Dysmenorrhoea } \\
\hline 34 & 03 & $31(91.2)$ & 53.357 & $<0.00001$ \\
\hline \multicolumn{5}{|c|}{ Menstrual Irregularities } \\
\hline 23 & 01 & $22(95.7)$ & 38.420 & $<0.00001$ \\
\hline
\end{tabular}


Table 4 shows most common presentations and their significant remissions with $\mathrm{P}<0.001$. Common presentations were lower abdomen pain 46(76.66\%), dysmenorrhea $34(56.66 \%)$ and $23(38.33 \%)$ were menstrual irregularities. This result does not agree with A.EI. Gergawy et al., who reported that the menstrual irregularities were the most common presentation in both groups [12 (48\%), $13(52 \%)$ respectively] followed by infertility and abdominal pain. Majority of the participants got complete remission of symptoms vide table-4, two participants of lower abdomen pain and three of dysmenorrhoea had persistent pain, but less severe. The results are assessed as cured, relieved and no response. Overall, complete cyst resolution and remission of symptoms seen in 36(60.0\%) participants assessed as cured, 24 (33.33\%) shows no response to trial and 04 participants $(6.67 \%)$ categorized under relieved result exhibited reduction in cyst size and mild symptoms. No complications were observed in our study during or after trial.

Table 3: Distribution of study participants according to demographic characteristics and temperament

\begin{tabular}{|c|c|c|c|c|c|c|c|c|c|c|c|}
\hline \multicolumn{4}{|c|}{ Marital status } & \multicolumn{3}{c|}{ Occupation } & \multicolumn{3}{c|}{ Temperament } & \multicolumn{2}{c|}{ Socio-economic status } \\
\hline \multicolumn{2}{|c|}{ Married } & Unmarried & Housewives & Employee & Student & Balgami & Damvi & Safrvi & Middleclass & Lowerclass & Upperclas \\
\hline $\mathrm{N}$ & 45 & 15 & 38 & 14 & 8 & 31 & 18 & 11 & 27 & 22 & 11 \\
\hline$\%$ & 75.0 & 25.0 & 63.3 & 23.3 & 13.3 & 51.7 & 30.0 & 18.3 & 45.0 & 36.7 & 18.3 \\
\hline
\end{tabular}

\section{Conclusion}

Ovarian cysts are a common problem seen in reproductive age women and it is one of the common causes of abdominal pain, menstrual irregularities, infertility affecting the physical, psychological and social health of women. Ancient Unani physicians without any sophisticated techniques had put forth many hypothesis regarding ovarian disorders, infertility or symptoms like menstrual irregularities and other gynecological disorders etc, and mentioned a lot of literature in their authentic books regarding causes, management and treatment. Unani single drugs and compound formulations with excellent efficacy have been used to treat these conditions. The drugs used in the study are proven to be beneficial and cost-effective in the treatment of this disease. For future researchers, multicentre studies are recommended.

\section{Acknowledgements}

I would like to sincerely acknowledge Dr.ntruhs, Vijayawada,AP, for allowing us to conduct this study. Without their permission this study would have never been performed.

Funding: No funding sources

Conflict of Interest: None Declared.

\section{References}

1. Royal College of Obstetrics and Gynecology. 2013 June; www.rcog.org.uk/womenshealth/clinical-guidance/ovarian-massespremenopausal-women-managementsuspected-green-top-62

2. G.J. Tortora's .Principles of Anatomy \& Physiology, 15th Edn, published by John Wiley \& Sons; 2017: 1073, 1103.

3. The American College of Obstetricians and Gynecologists. Ovarian Cysts, 2017; https://www.acog.org/patientresources/faqs/gynecologic-problems/ovariancysts

4. Howkins \& Bourne Shaw's Textbook of Gynaecology, 16th Edn, published by Reed Elsevier India Private Limited; 2015: 429.

5. D.C. Dutta's Textbook of Gynecology including Contraception, Enlarged \& Revised Reprint,6th Edn, published by Jaypee Brothers Medical Publishers (P) Ltd, New Delhi, India. 2013: 289.

6. Trish Chudleigh \& Basky Thilaganathan, Obstetric Ultrasound How, Why and When, 3rd Edn, Published by Elsevier Limited 2004: 76.

7. C. S. Ou, Y. H. Liu,V. Zabriskie, and R. Rowbotham, Alternate methods for 
laparoscopic management of adnexal masses greater than $10 \mathrm{~cm}$ in diameter, Journal of Laparoendoscopic and Advanced Surgical Techniques. 2001, vol: 11; 125-132

8. A. Alobaid et al-Laparoscopic Management of Huge Ovarian Cysts, Hindawi Publishing Corporation Obstetrics and Gynecology International Volume, 2013; http://dx.doi.org/10.1155/2013/380854

9. Guy Rofe et al- Benign ovarian cysts in reproductive-age women undergoing assisted reproductive technology treatment, Open Journal of Obstetrics and Gynecology, 2013; 17-22,

http://dx.doi.org/10.4236/ojog.2013.37A1005 (http://www.scirp.org/journal/ojog/).

10. William's Gynecology, 2nd Edn, published by McGraw-Hill, 2012: 266, 263.

11. Gupta P et al., Management of Ovarian Cysts with Percutaneous Aspiration and Methotrexate Injection. Niger Med J. Jan-Feb 2016; 57(1):19-23. doi: 10.4103/0300-1652.180566.

12. A. El Gergawy et al.,Efficacy of Intra-Cystic Methotrexate Injection in Management of Benign Persistent Ovarian Cysts, Open Journal of Obstetrics and Gynecology, 2017: 51-60 http://www.scirp.org/journal/ojog .

13. S A Farghaly-Current diagnosis and management of ovarian cysts; Clinical and Experimental Obstetrics \& Gynecology, 01 Jan 2014, 41(6):609-612 PMID: 25551948

14. Parity and risk of ovarian cysts: Cross-sectional evidence from the Dongfeng-Tongji cohort study, Journal of Huazhong University of University of Science and Technology[Medical Sciences],october2016, vol 36:767-771

15. Berek \& Novak's Gynecology, 15th Edn, Wolters Kluwer Lippincott Williams \& Wilkins,2012;754.

16. Mazhar h., The General Principles of Avicenna's Canon of Medicine, published by Idara Kitab-ul-Shifa, New Delhi,2007; 342.

17. Sayed Kamal Husain Hamdani, Usool-E- Tib, published by National Council For Promotion Of Urdu Language, Ministry of Education
Department of Higher Education Government of India, 1998; 58,138-140.

18. Hakeem Abdul Razzaq, Taalem-ul-Qabila; 323,338 .

19. Hakeem waseen Ahmed Azmi, Amraz-eNiswan, Aejaz Publishing House, 1995; 359.

20. Shafaqat Azmi, Amraz-e-Nisan;248-251.

21. Hakeem Ishtiyaq Ahmed, AL-Umur-AlTabai'yah(principles of human physiology in Tibb), published by Hakim(mrs) Nuzhat Ishtiyaq,New Delhi, 1980; 77,81-82,113.

22. Hakeem Kabeeruddin, Maqzan-ul-Mufaradaat, Aejaz Publishing House,New Delhi;74, 489,549.

23. National Formulary Of Unani Medicine,1stEdn:p3,6; Ministry of Health \& Family Welfare, Govt. of India, Dept.of Indian Systems of Medicine and Homeopathy, 2001,2011;110,103,135.

24. Standardisation of single drugs of Unani medicine,Part 2, Central Council for Research in Unani Medicine, Ministry of Health \& Family Welfare, Govt. of India, 1987;282-287.

25. Dr. K.M. Nadkarni's, Indian Metria Medica, Popular Prakash Pvt Ltd, Mumbai 2009, Vol:III , 720,582-84,1072-73.

26. Trease \& Evans. Pharmacognosy, 16th Edn, Published by Elsevier Limited, 2009; 305.

27. Anonymous. The Wealth of India - A Dictionary of Indian Raw Material and Industrial Products. CSIR, New Delhi, 2005; 151-154.

28. Current Diagnosis\& Treatment Obstetrics \& Gynecology, 11th Edn, The McGraw-Hill Companies,Inc. 2013, Chap:14;1156.

29. Nalini YL et al., A clinical study of large ovarian cyst with various presentations: Prospective interventional study, Int J Reprod Contracept Obstet Gynecol. 2018 Jan;7(1):23924. DOI: http://dx.doi.org/10.18203/23201770.ijrcog20175853. . www.ijrcog.org 